\title{
Planning Effective Educational Programs for Adult Learners
}

\author{
Hong Shi ${ }^{1{ }^{*}}$ \\ ${ }^{1}$ China University of Petroleum-Beijing, Changping District, Beijing 102299, China \\ *Correspondence: China University of Petroleum-Beijing, Changping District, Beijing 102299, China. E-mail: \\ hzs0032@auburn.edu
}

Received: March 2, 2017

Accepted: May 17, 2017 Online Published: June 14, 2017

doi:10.5430/wje.v7n3p79

URL: https://doi.org/10.5430/wje.v7n3p79

\begin{abstract}
Educational program planning is a complex ongoing process and planners should reflect on and consider for all of the involved factors, context, and people. The purpose of this study is to analyze how to plan effective educational programs for adult learners. Adult education is a developmental process and interacts with broad social events. Adult educators should be encouraged to look at events occurring in a larger context for program development. Program planners should consider adult learners' needs and interests to ensure program development and pedagogical approaches incorporate students' needs, expectations and experience into educational program.
\end{abstract}

Keywords: educational program; adult learner; program planning; social context

This work was supported by the China University of Petroleum-Beijing [grant numbers 2462017YJRC005].

\section{Introduction}

Educational program planning involves a series of decision making which can take place among different organizations, people, and activities (Caffarella, 1994). Adult learners have characteristics which are different from young learners including social roles of adult learners as parents and employees, obligations to work, family, and communities, abundant experience brought into classroom, and purposes of returning to university such as improving their working skills, developing their careers, and making a better life. According to Knowles (1990), adults are autonomous, self-directed, goal-oriented, and practical, and have accumulated work and life experience, family responsibilities and previous education. Besides, adult learners have barriers against participating educational programs such as limited time, transportation, motivation, interest, money, and confidence. Based on these characteristics of adult learners, educators should design curriculum and adopt instruction methods to meet the needs of adults and to ensure the continual process of learning for adults throughout their life. Unlike more traditional kinds of education, adults and continuing education should respond flexibly to the needs and interests of potential adult learners (Long, 1983).

\section{Planning Educational Program}

Rothwell and Cookson (1997) proposed a comprehensive Lifelong Education Program Planning (LEPP) model. In the model they identified four quadrants in program planning: "exercising professional responsibility, engaging relevant contexts, designing the program, and managing administrative aspects" (p.8).

According to Rothwell and Cookson (1997), exercising professional responsibility involves clearly making working philosophy, responsibility and role of educators. In other words, program planners should have their own values, ensure that program planning continually meets the needs of learners and develop training based on a moral framework (Kilgore, 2003). According to Kilgore (2003), program planners should pay attention to every step of planning process and consider for all of the people involved in an educational program. For example, they should reflect on their values and beliefs about education, and consider perspectives of all stakeholders involved in the program planning, developing needs of adult learners and teachers' professional development to ensure continually meet the needs of life learning of adults (Kilgore, 2003).

Schroeder (1980) proposes the importance of the linkage between educational programs and the broader society. Schroeder believes that adult and continuing education is a developmental process and the social change dimension 
of program development is important. Adult educators should be encouraged to look at events occurring in the larger society for program development ideas (Long, 1983). According to Long (1983), adult and continuing education interacts with broader social events including economic, political, and technological changes, and consequently program activity should be informed by an awareness of the implications of such events. Rothwell and Cookson (1997) propose that educational program planning requires assessing external and internal situations, learning needs and stakeholders' interests, and considering adult learners' characteristics (Rothwell and Cookson, 1997). According to Rothwell and Cookson (1997), social and economic conditions, labor market, legal and technological factors should also be considered in the program planning since these factors affect needs and interests of adults and cause the needs of adults change continually. To be specific, the factors include the required skills and qualities for adults in the workforce, available resources and technological innovations for adults' education and educational program, mission and goals of related organization or university, and related laws and government regulations to educational programs (Kilgore, 2003), and different organizations or universities and local government have different services to these adults based on their interests and ability, thus, all these factors should be considered in adult educational program planning (Mills, Cervero, Langone, \& Wilson, 1995).

\section{Understanding of Adult Learners}

Planning effective programs and services and helping adult learners succeed require a clear understanding of adult learners' needs and expectations and how adults learn. Andragogy, a theory of adult learning, makes assumptions about adult learners and the design of adult learning (Knowles, et al., 2005). The Council for Adult and Experiential Learning (CAEL) links learning and work and aims to help every college and university become an Adult Learning Focused Institution (ALFI) - one that offers specialized services to make it easier for adults to get the education and training they need and meet the unique needs of adult students. It emphasizes the importance of understanding the characteristics of the adult learner because of their non-traditional characteristics create needs and priorities which should be paid special attention when planning educational programs. Therefore, to ensure adult learners success and keep them enrolled, an educational program should be provided to meet their needs and expectations. Kilgore (2003) lists some adult learners' needs and learning characteristics which are unique to adult learners as well as significant to program planning. These characteristics include various roles of adult learners except for being students, obligations to work, family and the community except for course work, abundant experience brought into classroom, and the purpose of returning to the university is to learn and apply practical skills, develop their careers, and make a better life (Graham \& Donaldson, 1999). Adults are autonomous and self-directed (Knowles, 1990). Self-directedness requires adult learners to take responsibility to adopt their own learning strategies and assessment methods (Merriam \& Caffarella, 1991). Self-directed learning is "a process in which individuals take initiative, with or without the help of others, to diagnose their learning needs, formulate learning goals, identify resources for learning, select and implement learning strategies, and evaluate learning outcomes" (Knowles, 1975, p. 18). Thus, related instruction should help to increase adult learners' self-regulation, motivation, and confidence. Self-directed learners can achieve their goals by making continuous adjustments through interactions with their teachers and peers. Educational programs should help to increase interactions between teachers and learners and to ensure that adult learners get involved in their own learning process. Self-directedness involves motivation, strategies, self-awareness of performance, and sensitivity to environmental and social settings (Zimmerman \& Risemberg, 1997). The educational programs should help adult learners to get motivated, master effective learning strategies, and adapt to educational environment and social settings. Self-directed learning behaviors can be operationalized through the establishment of goals, the search for and use of materials and resources, the application of learning strategies, and the assessment of outcomes (Brookfield, 1985; Holec, 1981, 1985; Knowles, 1975; Pemberton, 1996; Lindley, 1986; Little, 1991; Oddi, 1987; Snow, 2006, 2010). Educational programs should assist adult learners to establish goals according to their own conditions, help them to know how to search for useful information and resources, enable learners to get access to all services, and provide different assessment methods to accommodate the special needs of adult learners. Dickinson (1979) also indicated that teachers can facilitate self-directed learning by assisting learners in the following ways: "(a) helping the learner to specify as precisely as possible what he wants to learn; (b) preparing the learner psychologically and methodologically for autonomy. Methodological preparation involves giving the learner techniques for 'teaching' himself; (c) acting as a resource reference for the learner, directing him to appropriate resources" (p. 185). The educational programs need to teach adult learners not only skills for career but also skills and capabilities for life-long learning. Although they have specific purposes to attend the educational programs, adult learners need to get accessible resources and techniques so that they can learn outside classrooms, solve problems and overcome challenges in their career and life. Self-direction skills allow learners to have a deeper 
understanding of themselves and their own learning process. Thus, educational programs should help to increase self-direction of potential learners.

Knowles (1990) based his andragogical model on several assumptions that describe how adults learn. According to Knowles, adults need to know why they must learn something before they will set about learning it. Relevance is the key concept. Making educational program relevant to the learner by recognizing the unique background and incorporating adult learners' experience into education is important. Adult learners need to know that new knowledge is relevant to their job, their family, and their life (Knowles, 1990). Program planners, therefore, should be aware of what they need to know. Adult learners have an established self-concept that includes an understanding of their capability to make decisions for themselves (Knowles, 1990). "Once they have arrived at that self-concept that develop a deep psychological need to be seen by others and treated by others as being capable of self-direction. They resent and resist situations in which they feel others are imposing their wills on them." (Knowles, 1990, p. 58). Program planners should consider the adult learners' preexisting self-concept. The sense of personal strength and weakness requires honest feedback that shapes the self-concept (Duffy \& Forgan, 2005). The most powerful motivators for most adults are those related to job satisfaction, self-concept, and quality of life (Knowles, 1990). According to Knowles (1990), the continual growth in some adults is blocked in others when a lack of resources, time or opportunity occurs. Program planners should find resources or look for opportunities to keep adult learners motivation high. In addition to, program planners have a responsibility to effectively work with various stakeholders with various needs and should be skilled in time and project management (Lincoln, 1991; Rothwell \& Cookson, 1997).

\section{Factors that Influence Program Planning for Adult Learners}

Jane Vella (2002) has built on Knowles' (1984) idea of adult learning theory and identifies 12 principles for effective adult learning. These principles should become key elements to consider in program planning for adult learners. Vella's Twelves Principles for Effective Adult Learning are as follows: needs assessment: participation of the learners in naming what is to be learned; safety in the environment and the process, and we create a context for learning, that context can be made safe; sound relationships between teacher and learner and among learners; sequence of content and reinforcement; praxis: action with reflection or learning by doing; respect for learners as decision maker; ideas, feelings, and actions: cognitive, affective, and psychomotor aspects of learning; immediacy of the learning; clear roles and role development; teamwork and use of small groups; engagement of the learners in what they are learning; accountability: how do they know they know? These factors are vital for planners to consider when planning educational program for adult learners.

Knowles, et al. (2005) proposes factors which should be focused in the training or educational program development including relevant and immediate usefulness of material to learners, welcoming training environment, engaging training presentation, and a respectful presenting manner in training so that learners can share their experiences.

CAEL developed the Principles of Effectiveness for Serving Adult Learners to help institutions evaluate their effectiveness in serving adults and improve their adult learners' services. Colleges and universities have used the tools to develop strategic plans and to focus on adult learner needs. The principles can help to make educational opportunities more accessible for adult learners. These principles are useful and effective guidance for educational program planning for adult learners. According to CAEL website (2014), these principles are as follows: Outreach, that is, conducting its outreach to adult learners by overcoming barriers in time, place, and tradition in order to create lifelong access to educational opportunities. Potential students need to be aware of programs that meet their needs and need to know how to access these programs. Adult learners are not just interested in personal enrichment but also in retraining, refreshing workplace skills, and preparing for new careers. The outreach strategies need to acknowledge those very real goals and show how the institution is prepared to help the adult learner reach them (Klein-Collins, 2011); Plan life and career according to learners' life and career goals in order to help learners reach their goals; Increase financial flexibility by using various payment options for adult learners; Assess learning outcomes such as knowledge, skills, and competencies acquired by adults according to curriculum and work requirement and "what students learn and how this learning results in changes in participants" (Caffarella, 1994, p.23); Use various teaching methods to make the curricular concepts relevant to practical knowledge and skills; Assist learners by providing student support systems to help students to gain abilities to become self-directed, lifelong learners; Use technology to provide learners timely and valuable information to promote the effectiveness of educational program; Involve in relevant relationships, partnerships, and collaborations with employers and related organizations to provide educational and career opportunities for learners; Provide supports and services for learners 
to get access to college or institution's programs to ensure that programs help learners to apply their skills and knowledge and achieve their educational and career goals successfully (www.cael.org, 2014).

These principles provide guidelines for program planners to follow so that they can decide what can be covered in programs. London (1960) identifies five steps in program development: determine the needs of the constituents; enlist their participation in planning; formulate clear objectives; design a program plan; plan and carry out a system of evaluation. Generally speaking, when planning educational programs for adult learners, the following aspects should be considered: target audience and their needs, learning objectives of programs, size of class, and approach adopted in the program instruction based on "what do the students need to learn?" (Northwest Center for Public Health Practice, 2012). This change of perspective will make educational program much more succeed for benefiting adult learners. The major parts of program designing include planning and making program goals, objectives and evaluation method, designing curriculum, instructional procedures and activities (Rothwell \& Cookson, 1997). A needs assessment should be conducted before taking on an educational program. It is helpful to identify gaps in learning and design the program suitable for learners (Kilgore, 2003). Needs assessment is a typical starting point for planning educational programs. Program planners should conduct formal or informal needs assessments from time to time to determine what their program's goals or purposes should be and what should be included in their program. Then, well-designed materials used in programs, which are determined by planners according to needs assessment, help reinforce learning objectives and outcomes (Northwest Center for Public Health Practice, 2012). According to A Toolkit for Teaching Adults developed by Northwest Center for Public Health Practice, it is important to have high-quality and interactive courses, and the high-quality online course or program should be learner-focused. According to Kilgore (2003), instructional design, learning procedures and methods and evaluation methods should consider adult learners and available resources. For example, additional assistance can be provided to help learners to become familiar with the technology since adults have different access and skills in computer using.

\section{Conclusions}

This study analyzed the ways to effectively plan educational programs for adult learners. In the process of planning educational programs for adult learners, adult learners' needs and expectations and how adults learn should be considered to make sure the programs designed to serve adult learners effectively. Educational programs should be learner-centered. Program planning for adult learners should be continual, flexible, comprehensive and accessible. Since the needs of adult learners change with different external and internal context, a program planner's work is a long-term process to provide services and education opportunities to these learners. The program planning is a complex ongoing process. Future studies can examine more involved factors, context, and people in a larger context for program planning and implement experiments to investigate effective ways to design and plan adult educational programs.

\section{References}

Brookfield, S. (1985). Self-directed learning: A critical review of research. In S. Brookfield (Ed.). Self-directed learning: From theory to practice. (pp. 5-16). New directions for continuing education; no. 25. San Francisco: Jossey-Bass. https://doi.org/10.1002/ace.36719852503

Caffarella, R. S. (1994). Planning Programs for Adult Learners. San Francisco: Jossey-Bass.

Dickinson, L. (1979). Self-instruction in commonly-taught languages. System, 7, 181-186. https://doi.org/10.1016/0346-251X(79)90001-0

Duffy, Mary Lou \& Forgan, James W. (2005). Mentoring new special education teachers: A guide for mentors and program developers. Thousand Oaks, Calif.: Corwin Press. https://doi.org/10.4135/9781483328898

Graham, S., \& Donaldson, J.F. (1999). Adult students' academic and intellectual development in college. Adult Education Quarterly, 49(3), 147-161. https://doi.org/10.1177/074171369904900302

Holec, H. (1981). Autonomy and foreign language learning. Oxford: Pergamon.

Holec, H. (1985). On Autonomy: Some elementary concepts. In Riley, P. (Ed.), Discourse and Learning (pp.173-190). London: Longman.

Kilgore, Deborah (2003). Planning programs for adults. New Directions for Student Service, 102, 81-88. https://doi.org/10.1002/ss.92

Klein-Collins, Rebecca. (2011). Strategies for Becoming Adult-Learning-Focused Institutions. AAC\&U. 
Knowles, M. (1984). Andragogy in action: Applying modern principles of adult learning. San Francisco: Jossey-Bass.

Knowles, M. S. (1975). Self-directed Learning. New York: Association Press.

Knowles, M.S. (1990). The adult learners: A neglected species ( $4^{\text {th }}$ ed.). Houston, TX: Gulf Publishing.

Knowles, M.S., Holton, E.F. III, \& Swanson, R.A. (2005). The adult learner: The definitive classic in adult education and human resource development $\left(6^{\text {th }}\right.$ ed.). Burlington, MA: Elsevier, Inc.

Lincoln, Y. S. (1991). The arts and sciences of program evaluation. Evaluation Practice, 12(1), 1-7.\# https://doi.org/10.1016/0886-1633(91)90018-S

Lindley, R. (1986). Autonomy. London: Macmillan. https://doi.org/10.1007/978-1-349-18428-6

Little, D. (1991). Autonomy: Definitions, issues and problems. Dublin: Authentik.

Long, Huey B. (1983). Adult and continuing education: Responding to change. New York: Teachers College, Columbia University.

Merriam, S. B., \& Caffarella, R. S. (1991). Learning in adulthood. San Francisco: Jossey-Bass.

Mills, D. P., Cervero, R.A., Langone, C.A., \& Wilson, A.L. (1995). The impact of interests, power relationships, and organizational structure on program planning: A case study. Adult Education Quarterly, 46(1), 1-16. https://doi.org/10.1177/0741713695046001001

Northwest Center for Public Health Practice. (2012). A Toolkit for teaching adults. School of Public Health, University of Washington.

Oddi, L. F. (1987). Perspectives on self-directed learning. Adult Education Quarterly, 38(1), 21-31.\# https://doi.org/10.1177/0001848187038001003

Pemberton, R. (1996). Introduction. In Pemberton et al. (Eds.). Taking Control: Autonomy in Language Learning (pp.1-8). Hong Kong: Hong Kong University Press.

Rothwell, W.J., \& Cookson, P.S. (1997). Beyond instruction: Comprehensive program planning for business and education. San Francisco: Jossey-Bass.

Snow, D. (2010). Autonomy and strategizing in self-directed language learning. Asian Journal of English Language Teaching, 20, 27-46.

Snow, D. (2006). Selling self-directed language learning. Review of Applied Linguistics in China, 2. Retrieved from www.sfs.nju.edu.cn/edit/UploadFile/200612219310201.doc

Vella, J. (2002). Learning to listen, learning to teach: The power of dialogue in educating adults. San Francisco: Jossey-Bass.

Zimmerman, B. J., \& Risemberg, R. (1997). Self-regulatory dimensions of academic learning and motivation. In G. D. Phye (Ed.), Handbook of academic learning: Construction of knowledge. (pp. 105-125). New York: Academic Press. https://doi.org/10.1016/B978-012554255-5/50005-3 